\title{
NOVEL CHAT SEBAGAI INOVASI MEDIA PEMBELAJARAN SOSIOLOGI MATERI BENTUK INTERAKSI SOSIAL
}

\author{
Bima Sayoga Putra, Yerry Soepriyanto, Susilaningsih \\ Teknologi Pendidikan, Fakultas Ilmu Pendidikan, Universitas Negeri Malang. \\ Jl. Semarang No.5, Malang, 65145, Indonesia. \\ yerry.soepriyanto.fip@um.ac.id
}

Article History

Received: 15 Maret 2021, Accepted: 07 April 2021, Published: 20 Februari 2022

\begin{abstract}
Abstrak
Penelitian dan pengembangan ini bertujuan untuk menghasilkan produk berupa media novel chat sebagai inovasi media pembelajaran sosiologi materi bentuk interaksi sosial. Research and Development atau penelitian dan pengembangan merupakan salah satu metode penelitian dalam menghasilkan produk. Metode pengembangan yang dipakai dalam pembuatan produk adalah model Borg \& Gall yang telah disesuaikan oleh kebutuhan pengembang (pencarian dan pengumpulan informasi, perencanaan, mengembangkan produk, uji kelayakan produk, revisi hasil uji kelayakan produk, uji coba lapangan, dan penyempurnaan produk akhir). Dalam penerapannya media novel chat menjadi pelengkap dalam proses pembelajaran sosiologi, yang berarti media diprogramkan untuk melengkapi materi pembelajaran yang diterima siswa di dalam kelas. Hasil dari uji kelayakan produk yang telah diujikan kepada ahli produk dan ahli materi serta dilakukan uji coba lapangan kepada siswa, menunjukkan bahwa media novel chat mendapatkan tanggapan positif dan layak. Sehingga dapat disimpulkan bahwa media novel chat dapat digunakan sebagai media pembelajaran sosiologi, serta dengan adanya media novel chat siswa memiliki rasa kemudahan, kemenarikan dan motivasi dalam pembelajaran.
\end{abstract}

Kata kunci: Media Pembelajaran; Novel Chat; Sosiologi; Interaksi Sosial

\begin{abstract}
This research and development aims to produce a product in the form of novel chat media as an innovation in sociology learning media for the form of social interaction. Research and Development or research and development is one of the research methods in producing products. The development method used in the manufacture of the product is the Borg \& Gall model that has been adapted to the needs of the developer (information search and collection, planning, product development, product feasibility testing, revision of product feasibility test results, field trials, and final product improvement) In its application, the novel chat media is a complement to the sociology learning process, which means that the media is programmed to complement the learning material that students receive in the classroom. The results of the product feasibility test that has been tested on product experts and material experts as well as field trials conducted on students show that the novel chat media gets a positive and feasible tanggapanse. So it can be concluded that the novel chat media can be used as a sociology learning medium, and with the novel chat media students have a sense of ease, attractiveness and motivation in learning.
\end{abstract}

Keyword: Learning Media; Novel Chat; Sociology; Social Interaction 


\section{PENDAHULUAN}

Pesatnya pertumbuhan ilmu pengetahuan serta teknologi kala ini telah membawa pengaruh yang besar pada segala bidang kehidupan manusia, seperti pada bidang pendidikan. Pembelajaran ialah salah satu aspek yang bisa memastikan pertumbuhan suatu negeri, kenaikan kualitas pembelajaran ialah salah satu strategi pembangunan pembelajaran di indonesia (Sudarsana, 2016). Pendidikan sekarang wajib disesuiakan dengan pertumbuhan zaman, yaitu pendidikan tidak cukup mengutamakan kecerdasan intelektual saja, namun kepintaran spiritual dan kepintaran emosional juga menentukan keberhasilan tercapainya tujuan pendidikan. Salah satu tujuan pembelajaran sosiologi ialah membekali siswa dengan keterampilan dasar berpikir logis dan keterampilan berpikir kritis, rasa ingin tahu, keterampilan inkuiri, keterampilan pemecahan masalah, dan keterampilan dalam kehidupan sosial (Angraeny \& Awaru, 2018). Upaya tersebut memiliki peran yang strategis dalam kerangka pembangunan nasional di seluruh Indonesia dan melibatkan dalam penyiapan sumber daya manusia untuk pembangunan masa depan. Pemerintah terus tingkatkan kualitas pendidikan dengan mengembangkan kurikulum 2013 yang menitikberatkan pada pembelajaran siswa yang berpusat dan mandiri (Machali, 2014).

Teknologi komunikasi berkembang sangat pesat sehingga yang melatari pengembangan kurikulum 20013 saat ini, sehingga di pendidikan saat ini dirasakan mengalami pergeseran dan perubahan. Abad 21 ini pendidikan berada dalam era pengetahuan (knowledge age), dan pertumbuhan pengetahuan telah mengalami percepatan yang luar biasa. Akselerasi ilmu pengetahuan yang semakin banyak didukung oleh media digital dan teknologi yang disebut informasi superhighways (Wijaya et al., 2016). Selaras dengan itu, Kementerian Pendidikan dan Kebudayaan berkeyakinan bahwa dalam pembelajaran periode 21 menekankan bahwa siswa wajib memiliki kemampuan untuk menemukan dari berbagai sumber, membereskan suatu permasalahan, berfikir analitis, dan berkolaborasi untuk membereskan masalah.

Dalam pendidikan Sekolah Menengah Atas di negara indonesia terdapat mata pelajaran sosiologi. Sosiologi merupakan suatu mata pelajaran di jurusan ilmu-ilmu sosial yang mempelajari tentang berbagai kenyataan serta peristiwa sosial, memahami teori serta membereskan masalah sosial yang ada di lingkungan sosial masyarakat (Primasari et al., 2017). Auguste Comte (17981857) adalah tokoh awal kali yang mengusulkan istilah sosiologi, dia merupakan orang prancis sebagai filsuf yang diingat sebagai ayah sosiologi. Kata sosiologi berasal dari dua suku kata yaitu socious (bahasa latin) yang berarti teman, dan logos (bahasa yunani) yang berarti pembicaraan atau perkataan (Maksum, 2016). Sosiologi memiliki beberapa konsep yaitu sosialisasi, kelompok sosial, perubahan sosial, konflik, struktur sosial, dan lembaga sosial. Pengertian dasar sosiologi ada dua, yaitu selaku metode dan selaku ilmu. Sosiologi selaku metode adalah cara berpikir yang dapat mengungkap kenyataan masyarakat terkait aktivitas sosial melalui teori dan prosedur yang terbukti secara ilmiah, sedangkan sosiologi selaku ilmu adalah tentang kumpulan pengetahuan masyarakat beserta budayanya yang berdasarkan analisis pemikiran logis yang disusun secara sistematis (FIDA, 2016).

Sosiologi harus diajarkan kepada peserta didik dengan benar untuk mencapai tujuan pembelajaran sosiologi. Perlu adanya media pembelajaran sebagai alat bantu yang efektif untuk dipergunakan sebagai pelengkap komunikasi dalam proses kegiatan pembelajaran dalam kelas (Sihkabuden, 2011). Berdasarkan pembelajaran sebelumnya dalam proses pembelajaran sosiologi materi bentuk interaksi sosial media yang dipakai adalah berita. Menurut KBBI, berita adalah cerita atau kelengkapan mengenai kejadian atau peristiwa yang hangat. Dengan memanfaatkan berita diharapkan peserta didik dapat mengenali dan mengidentifikasi berbagai kenyataan individu, kelompok, dan masyarakat dalam berinteraksi sosial. Tetapi berita hanya memuat satu kejadian atau satu peristiwa, dan didalam berita tidak terdapat proses dan contoh bentuk-bentuk interaksi 
sosial yang begitu jelas, sehingga siswa masih mengalami kebingungan dalam menerapkan sosiologi di kehidupan masyarakat di sekitarnya.

Media berisikan berbagai kumpulan cerita masyarakat dalam melakukan interaksi sosial adalah novel. Novel merupakan sebuah karya sasta yang disajikan dengan halus yang mengungkap kemanusiaan yang lebih dalam (Nurgiyantoro \& Efendi, 2013). Novel merupakan karya sastra dengan berbagai pengalaman karakter yang digunakan untuk menyajikan cerita secara sistematis dan yang paling lengkap. Novel digunakan sebagai penyajian cerita secara lengkap dan sistematis yang merupakan karya sasta dengan pengalaman karakter yang paling lengkap. Menurut Semi (1998) novel mengungkapkan suatu konsentrasi kehidupan pada suatu saat tegang, dan memusatkan dengan kehidupan tegas (Uli et al., 2017). Novel memberikan bentuk berbagai cerita tentang kehidupan seseorang dalam bermasyarakat. Menurut Nurgiyantoro novel dapat menawarkan sebuah dunia, yaitu dunia yang berisikan model dunia kehidupan dan dunia imajinasi yang khayalan, yang dikembangkan melalui berbagai unsur intrinsiknya seperti tokoh, latar, peristiwa, plot cerita, sudut pandang, dan lainnya yang semuanya bersifat imajinatif. Sebuah novel yang bagus dan baik adalah novel yang mampu diresapi dan dapat memunculkan nilai-nilai yang positif (Nurhuda et al., 2017).

Dari penjelasan diatas maka dikembangkanlah media pembelajaran berupa novel chat. Novel chat adalah karangan prosa yang mengandung rangkaian cerita yang dikemas dengan bentuk tampilan chatting. Media novel chat dalam proses pembelajaran berfungsi sebagai pelengkap atau komplemen. Media dikatakan sebagai komplemen berarti media diprogramkan untuk melengkapi materi dalam pembelajaran yang akan diterima siswa di ruang kelas (Kurniawan, 2017). Novel chat ini dikembangkan dengan aplikasi joylada yang terdapat di sistem operasi android maupun ios. Joylada merupakan penyedia layanan berupa platform media untuk mereka yang tertarik dalam menulis (Penulis) dan mereka yang menyukai membaca (Pembaca). Novel di joylada memiliki kemenarikan karena cerita dan dialog antar tokoh dikemas dalam tampilan chatting, sehingga pembaca akan merasakan rasa nyaman membaca novel dengan tampilan chat yang umum digunakan untuk berkomunikasi. Novel chat termasuk media pembelajaran jenis mobile learning karena beberapa pendapat para ahli yang mengemukakan kalau memanfaatkan model pembelajaran yang menggunakan perangkat mobile dalam mengaksesnya termasuk pembelajaran berbasis mobile (Martha et al., 2018).

Tujuan dari pengembangan ini adalah menghasilkan media pembelajaran berupa novel chat untuk pembelajaran sosiologi materi bentuk interaksi sosial. Diharapkan dengan adanya novel chat, siswa memiliki rasa kemudahan, kemenarikan, dan motivasi dalam pembelajaran. Selaras dengan tujuan pembelajaran sosiologi yaitu siswa dapat mengenali dan mengidentifikasi berbagai kenyataan individu, kelompok, dan interaksi sosial di masyarakat serta mampu membedakan proses interaksi sosial assosiatif dan dissosiatif sehinga mampu menempatkan diri dalam aktivitas sosial di masyarakat.

\section{METODE}

Metode yang dipakai atau research dalam penelitian (R\&D) menurut sugiyono (2011) untuk mengukur tingkat keefektifan media perlu metode penelitian yang menghasilkan media terstentu (Haryati, 2012). Model pengembangan media atau produk yang dipakai, mengacu pada Borg and Gall (2003) berpendapat bahwa didalam penelitian dan pengembangan, tahapan-tahapannya merupakan sebuah siklus penelitian lapangan yang berkaitan dengan produk yang dihasilkan yang meliputi kajian terhadap temuan penelitian. Borg \& Gall menyatakan bahwa prosedur penelitian pengembangan ada 10 langkah, yaitu: Research and information collecting (pencarian dan pengumpulan data), Planning (perencanaan), Develop preliminary form of product 
(mengembangkan bentuk produk awal), Preliminary field testing (uji coba lapangan awal), Main product revision (revisi hasil uji coba lapangan awal), Main field testing (uji coba lapangan utama), Operational product revision (revisi produk operasional), Operational field testing (uji coba lapangan operasional), Final product revision (penyempurnaan produk akhir), dan Dissemination and implementation (diseminasi dan implementasi).

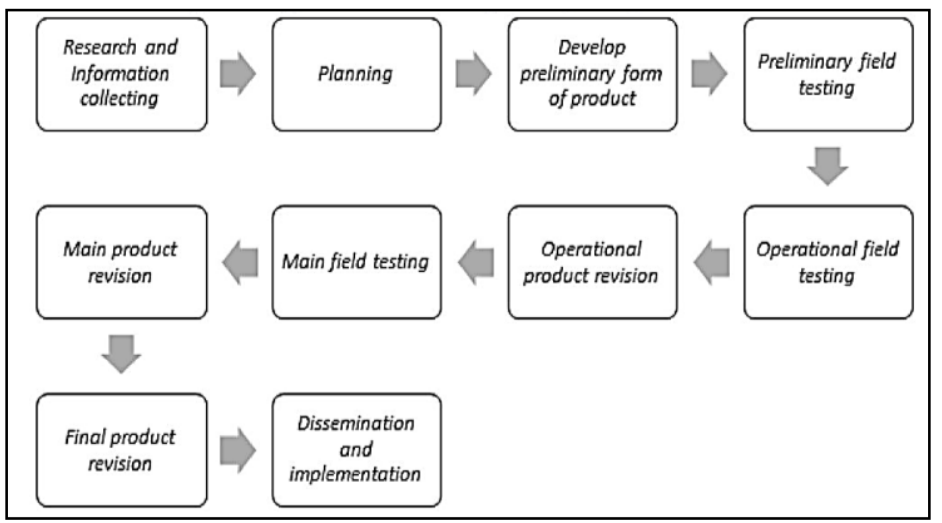

Gambar 1. Model R\&D Borg and Gall (2003)

Mengingat adanya kendala pandemi Covid-19, penerapan langkah-langkah tersebut disesuaikan dengan kebutuhan. Penyesuaian ini tentunya menunjuk pada ketentuan pengembangan suatu produk yang selaras dengan langkah-langkah yang telah dijelaskan oleh Borg \& Gall, penyesuaian ini meliputi 7 pokok tahapan, yaitu pencarian dan pengumpulan informasi, perencanaan, mengembangkan produk, uji kelayakan produk, revisi hasil uji kelayakan produk, uji coba lapangan, dan penyempurnaan produk akhir. Dengan metode Borg \& Gall pengembang melakukan uji kelayakan untuk mencari aspek relevasi, kemudahan dan kemenarikan media novel chat serta melakukan uji coba lapangan untuk mengetahui aspek kemudahan, kemenarikan dan motivasi siswa dalam pembelajaran sosiologi.

\section{HASIL}

Pada langkah pengumpulan informasi dari hasil observasi berupa data awal yang dilakukan untuk menganalisis kebutuhan media pembelajaran dan karakteristik siswa. Dari observasi yang dilakukan didapatkan informasi bahwa media yang digunakan guru dalam menyampaikan materi di dalam kelas meliputi buku, berita, power point, dan papan tulis. Dari hasil observasi karakteristik siswa didapatkan bahwa siswa kelas X jurusan IIS di SMAN 1 Grogol Kediri semuanya memiliki smartphone baik itu dengan sistem operasi android bahkan ios. Siswa juga menyatakan kalau papan tulis, berita dan power point sebagai media pembelajaran kurang menyenangkan, sehingga membuat siswa cepat jenuh dan sulit untuk memahami materi yang disampaikan. Sehingga dapat disimpulkan bahwa di SMAN 1 Grogol Kediri membutuhkan media pembelajaran berupa novel chat sebagai inovasi media pembelajaran sosiologi materi bentuk interaksi sosial.

Hasil dari tahap perencanaan meliputi menentukan tujuan pengembangan yaitu menghasilkan media pembelajaran berupa novel chat untuk pembelajaran sosiologi materi bentuk interaksi sosial. Serta membuat rencana pelaksanaan pembelajaran dengan memanfaatkan media novel chat sebagai pelengkap pembelajaran. Selanjutnya pengembang membuat kisi-kisi angket penilaian beserta butirnya, kisi-kisi pada ahli media terdapat aspek kemudahan dan kemenarikan. Kisi-kisi pada ahli materi meliputi aspek identitas, relevansi, kemudahan dan kemenarikan. Sedangkan kisikisi pada siswa terdapat aspek kemudahan, kemenarikan dan motivasi. 
Pada tahap pengembangan produk memperoleh ide cerita dengan judul Kenapa Dia Misterius. Novel tersebut bercerita tentang dua kelompok siswa yang berselisih mendapatkan hukuman berupa menyelidiki dua siswa misterius di sekolahnya, kelompok pertama menyelidiki siswi dengan kepribadian pendiam dan tidak berinteraksi dengan teman sekolahnya dan kelompok kedua menyelidiki siswa penyendiri di sekolah namun aktif di luar sekolah. Dalam cerita novel tersebut terdapat berbagai bentuk interaksi sosial baik itu bentuk asosiatif maupun disosiatif. Setelah mendapatkan ide cerita pengembang membuat desain karakter dan menerapkannya ke tampilan novel berbentuk chat dengan menggunakan aplikasi joylada yang tersedia di android maupun ios. Di joylada sudah tersedia layout tampilan beserta fitur aplikasinya, jadi pengembang cukup dengan mengupload gambar tokoh beserta percakapan antar tokoh.

Ahli media dan ahli materi adalah sebagai uji kelayakan produk yang merupakan proses penilaian produk oleh para ahli yang sesuai dalam bidangnya. Uji kelayakan produk dilaksanakan guna mengetahuai tanggapan dan saran mengenai media pembelajaran yang dikembangkan berkaitan dengan kualitas isi materi dan kualitas media pembelajaran yang dikembangkan. Uji kelayakan produk dan uji coba lapangan menggunakan lembar angket dan hasil tanggapan diukur dengan rating scale yang terdiri dari 4 kriteria jawaban dan dikelompokkan menjadi tanggapan positif dan tanggapan negatif. Tanggapan positif dengan poin 4 dan 3 , sedangkan negatif dengan poin 2 dan 1.

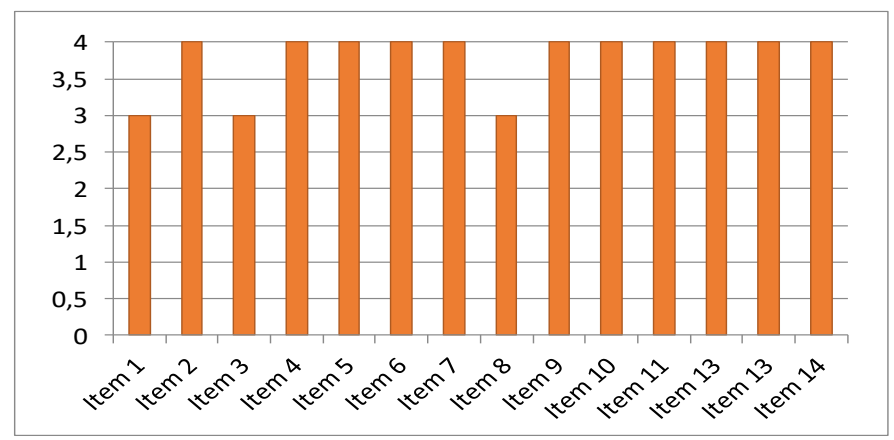

\section{Grafik 1. Hasil Tanggapan Ahli Media}

Pada grafik 1, hasil analisis uji kelayakan produk yang dilakukan kepada ahli media, secara keseluruhan mendapatkan tanggapan positif dengan persentase $100 \%$ yang terdiri dari 14 item pernyataan. Dari hasil analisis tersebut bahwa media novel chat mendapatkan tanggapan positif dari ahli media sehingga dapat ditarik kesimpulan bahwa media novel chat layak digunakan sebagai media pembelajaran kelas.

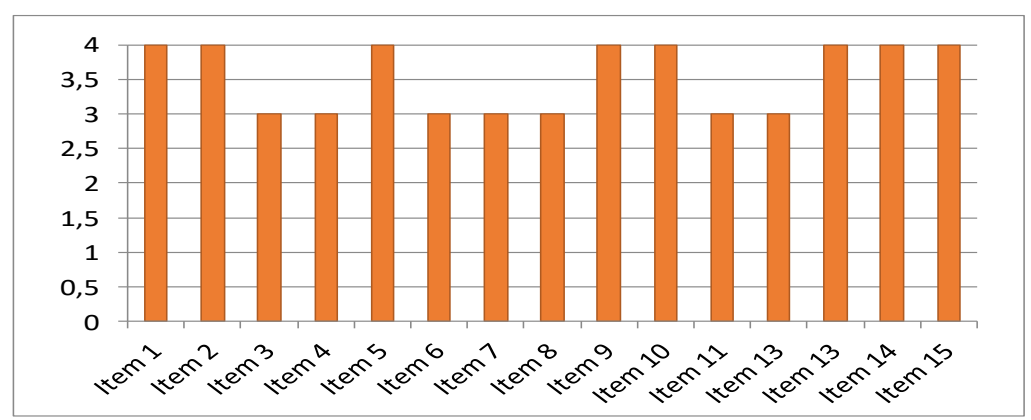

Grafik 2. Hasil Tanggapan Ahli Materi

Pada grafik 2, hasil analisis uji kelayakan produk yang dilaksanakan oleh ahli materi, secara keseluruhan mendapatkan tanggapan positif dengan persentase $100 \%$ dari 15 item pernyataan. Berdasarkan hasil analisis tersebut media novel chat layak digunakan dalam proses pembelajaran. 
Berdasarkan setelah melakukan uji kelayakan produk dari ahli media dan ahli materi, media novel chat perlu dilakukan revisi terkait bahasa dalam novel dan adegannya. Bahasa yang digunakan masih belum komunikatif dan belum efektif sedangkan adegan perlu diperjelas mengenai adegan bentuk interaksi sosial mediasi, akulturasi dan persaingan.

Tabel 1. Hasil Tanggapan Siswa

\begin{tabular}{|c|c|c|c|c|c|c|}
\hline \multirow{2}{*}{ Pernyataan } & \multicolumn{4}{|c|}{ Jumlah Pemilih } & \multirow{2}{*}{$\begin{array}{c}\text { Persen } \\
\text { tase }\end{array}$} & \multirow{2}{*}{$\begin{array}{r}\text { Rata } \\
\text { rata }\end{array}$} \\
\hline & SS & $\mathrm{S}$ & KS & TS & & \\
\hline Teks atau tulisan mudah dibaca & 20 & 12 & & & $91 \%$ & 3,6 \\
\hline Tata letak novel chat sederhana dan mudah dipahami & 17 & 14 & 1 & & $88 \%$ & 3,5 \\
\hline Novel chat mudah diakses & 15 & 14 & 3 & & $84 \%$ & 3,4 \\
\hline Novel chat mudah dioperasikan & 14 & 17 & 1 & & $85 \%$ & 3,4 \\
\hline Bahasa mudah dipahami & 12 & 19 & 1 & & $89 \%$ & 3,5 \\
\hline Alur cerita mudah dipahami & 17 & 13 & 2 & & $87 \%$ & 3,5 \\
\hline Cover menarik dan sesuai dengan cerita & 16 & 12 & 4 & & $84 \%$ & 3,4 \\
\hline Gambar avatar tokoh karakter jelas dan menarik & 18 & 13 & 1 & & $88 \%$ & 3,5 \\
\hline Stiker animasi menarik & 18 & 13 & 1 & & $88 \%$ & 3,5 \\
\hline Tampilan sederhana dan menarik & 20 & 11 & 1 & & $90 \%$ & 3,6 \\
\hline Antusias dalam mengikuti kegiatan pembelajaran & 13 & 17 & 1 & 1 & $83 \%$ & 3,3 \\
\hline Menimbulkan keingintahuan belajar secara mendalam & 14 & 14 & 4 & & $84 \%$ & 3,3 \\
\hline Menggunakan media secara berulang-ulang & 7 & 20 & 5 & & $77 \%$ & 3,1 \\
\hline Total & & & & & $85 \%$ & 3,4 \\
\hline
\end{tabular}

Uji coba lapangan dilakukan kepada satu kelas yang terdiri 32 siswa kelas $\mathrm{X}$ jurusan IIS di SMAN 1 Grogol Kediri. Hasil uji coba media pembelajaran novel chat pada pembelajaran sosiologi materi interaksi sosial menghasilkan rata-rata 3,4 atau $85 \%$ dari $100 \%$. Hasil ini menunjukkan novel chat layak digunakan dalam proses pembelajaran.

Berdasar pada hasil ujicoba lapangan yang dilakukan kepada 32 siswa menunjukkan bahwa media novel chat tidak perlu adanya revisi untuk penyempurnaan produk akhir.

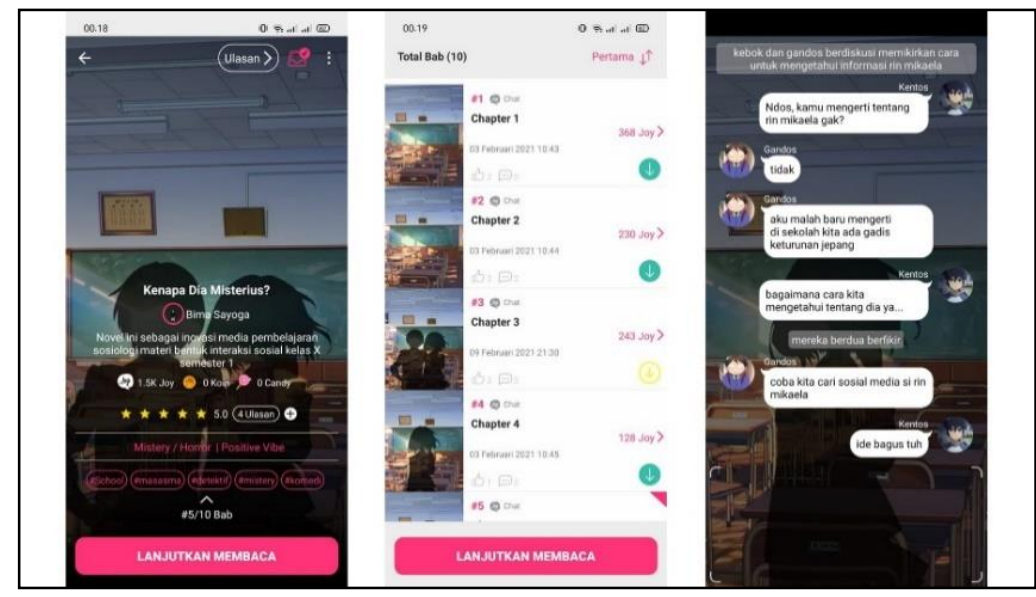

Gambar 2. Tampilan Media Novel Chat

\section{PEMBAHASAN}

Media novel chat yang dikembangkan telah melalui beberapa tahapan yang menunjuk pada model borg and gall. Uji kelayakan produk mendapatkan tanggapan dari ahli media dan ahli materi serta telah di uji cobakan di lapangan yang melibatkan 32 siswa jurusan IIS kelas X. Pada ahli media terdapat 2 aspek pernyataan yang diuji, yaitu aspek kemudahan dan aspek kemenarikan. Aspek kemudahan membahas tentang penggunaan bahasa yang jelas dan mudah serta fitur aplikasi untuk memberi kenyamanan dan kemudahan pada pengguna novel chat, sedangkan pada aspek kemenarikan berisikan tentang gambar, animasi, dan tampilan aplikasi yang menarik dan 
sederhana. Aspek-aspek tersebut keseluruhan berisikan 14 butir item pernyataan. Aspek kemudahan berisikan 9 butir pernyataan dan aspek kemenarikan berisikan 5 butir pernyataan. Hasil dari ahli media saat melakukan uji kelayakan produk bahwa media novel chat mendapatkan tanggapan positif dengan persentase $100 \%$ dan kalau digunakan sebagai media pembelajaran mendapat kategorisasi layak tanpa revisi dengan komentar media novel chat cukup bagus dan menarik tetapi perlu kemampuan imajisasi, kreatifitas dalam verbal tulisan.

Kemudian dilaksanakan uji kelayakan produk yang dilaksanakan oleh ahli materi. Uji kelayakan media novel chat ke ahli materi bertujuannya untuk mendapatkan kelayakan media, terkait kesesuaian isi media novel chat dengan tujuan pembelajaran sosiologi materi interaksi sosial. Pada ahli materi terdapat 4 aspek pernyataan yang diujikan, yaitu aspek identitas yang membahas tentang identitas mata pelajaran pada media, aspek relevansi berisikan tentang kesesuaian antara SK, KD, indikator, tujuan pembelajaran dengan isi yang disajikan dalam media pembelajaran, pada aspek kemudahan berisikan tentang cerita dan bahasa yang mudah dipahami, dan aspek kemenarikan tentang karakter tokoh dan peristiwa dalam cerita sangat menarik. Aspekaspek tersebut keseluruhan berisikan 15 butir item pernyataan yang terdiri dari 2 butir pernyataan pada aspek identitas, 3 butir pada aspek relevansi, 8 butir pada aspek kemudahan dan 3 butir pada aspek kemenarikan. Hasil saat dilakukan uji kelayakan produk yang dilaksanakan ahli materi mendapatkan tanggapan positif dengan persentase $100 \%$ dan novel chat sebagai media pembelajaran sosiologi mendapatkan kategorisasi layak dengan catatan revisi pada bahasa yang digunakan masih belum komunikatif dan belum efektif, serta perlu adanya tambahan adegan dalam cerita mengenai bentuk interaksi sosial akomodasi mediasi, akulturasi dan persaingan karena dalam cerita adegan tersebut kurang jelas.

Selanjutnya dilakukan proses uji coba lapangan yang melibatkan 32 siswa SMA kelas X jurusan IIS. Terdapat 3 aspek pernyataan yang diujikan, yaitu aspek kemudahan, aspek kemenarikan dan aspek motivasi. Aspek kemudahan membahas tentang kemudahan dalam belajar menggunakan media novel chat, aspek kemenarikan membahas tentang media memiliki tampilan menarik dan sederhana, serta aspek motivasi membahas tentang media dapat menimbulkan motivasi siswa dalam belajar. Seperti pada gambar 2, aspek kemudahan terdapat pada pernyataan nomor 1-6, aspek kemenarikan pada nomor 7-10, dan pada aspek motivasi terdapat pada nomor pernyataan 11-13. Sehingga secara keseluruhan berisikan 13 butir item pernyataan pada angket siswa. Hasil dari uji coba lapangan yang dilakukan kepada 32 siswa memperoleh rata-rata hasil keseluruhan 3,4 dari nilai maksimal yang diharapkan 4,0 atau $85 \%$ dari $100 \%$. Pada aspek kemudahan yang diujicobakan diperoleh persentase $87 \%$, pada aspek kemenarikan memperoleh sebesar $88 \%$, dan pada aspek motivasi diperoleh hasil $81 \%$.

Diketahui setelah melakukan uji coba lapangan, aspek motivasi siswa mendapatkan persentase yang rendah dibandingkan aspek-aspek lainnya. Dalam proses belajar, motivasi belajar sangat diperlukan karena dalam proses pembelajaran tidak akan berjalan baik jika tanpa motivasi belajar siswa yang tinggi. Media pembelajaran yang mudah, menarik dan sesuai kebutuhan siswa akan merangsang siswa menjadi minat dalam belajar (Sari, 2013). Namun perlunya hubungan positif antara siswa dengan guru dalam proses kegiatan pembelajaran, bahwa kenaikan motivasi siswa dalam belajar dipengaruhi dengan kinerja guru yang semakin tinggi, dan sebaliknya jika rendahnya motivasi siswa pasti disebabkan kinerja guru terjadi penurunan (Palupi, 2014). Selaras dengan penelitian (Widoyoko \& Rinawat, 2012), yang menyatakan kinerja guru dalam kelas mempunyai pengaruh yang positif yang signifikan terhadap motivasi belajar siswa. Mengingat waktu ini kondisi lingkungan belajar daring mengharuskan siswa dalam belajar harus di rumahnya masing-masing, guru tidak dapat mendampingi dan mendidik siswa secara langsung sehingga kurangnya interaksi guru dengan siswa, adanya sistem sekolah daring membuat guru tidak dapat 
melakukan tindakan positif dan negatif, tindakan tersebut seperti memberi hadiah, memuji, memberikan nasihat, menegur, dan menghukum. Siswa juga tidak bisa bermain dengan temannya di sekolah, padahal kegiatan tersebut dapat meningkatkan motivasi diri(Cahyani et al., 2020).

Mengemas pembelajaran supaya siswa dapat memiliki minat terhadap sosiologi terutama di dalam kelas perlu suatu upaya tersendiri untuk meningkatkannya. Menumbuhkan minat pada siswa dapat dilakukan dengan memberikan pengalaman-pengalaman tertentu pada siswa (Insriani, 2011). Tanpa adanya pengalaman dan hanya menerapkan teori saja, maka akan mengalami kurangnya minat belajar siswa dan kesulitan untuk menganalisis dan mencari solusi dari permasalahan di masyarakat (Rumianda et al., 2020). Pengalaman tersebut dapat menggunakan media pembelajaran novel chat, di dalam novel chat terdapat cerita tentang bentuk interaksi sosial antar individu, individu dengan kelompok, dan kelompok dengan kelompok, yang dapat membuat siswa memiliki pengalaman yang bermakna yang dapat membantu mereka untuk menyadari bahwa mereka adalah bagian dari masyarakat sosial. Penerapan novel chat dalam pembelajaran supaya siswa dapat mengamati, menganalisis, dan menyimpulkan hasil pengamatan mengenai cerita di novel chat sebagai dasar untuk memahami bentuk-bentuk interaksi sosial.

Novel chat dioperasikan melalui smartphone maka dari itu novel chat termasuk jenis media pembelajaran berbasis mobile learning karena penyampaian bahan pembelajaran ada pada smartphone dan dapat digunakan dimana saja dan kapan saja. Media pembelajaran berbasis mobile dapat meningkatkan sikap positif terhadap kinerja siswa, karena siswa menginginkan pengalaman belajar menggunakan smartphone, yang rasanya seperti mengerjakan pekerjan rumah yang dihabiskan lebih banyak waktu dalam menggunakan smartphone (Demir \& Akpinar, 2018). Selaras dengan penelitian yang dilakukan oleh (Rifai et al., 2020) bahwa siswa tertarik untuk menggunakan media mobile learning karena dalam pembelajaran menggunakan bahan dan alat serta media pembelajaran yang dekat dengan kebiasaan sehari-harinya. Apalagi ini adalah media novel chat yang cerita di dalamnya berbentuk tampilan chatting sehingga siswa merasa tidak asing dengan aktivitas sehari-harinya mengobrol melalui sosial media.

Media mobile learning dapat dikatakan sebagai pelengkap atau komplemen dalam pembelajaran meski tanpa bantuan dan pendampingan dari guru atau tutor apabila digunakan sebagai alat evaluasi, pemberian pengayaan, penguatan materi, dan dapat digunakan untuk mengulang kembali (recalling) dalam pembelajaran (Musahrain et al., 2017). Beberapa keistimewaan mobile learning, dimana merupakan layanan pembelajaran masa kini yang mudah dengan teknologi tanpa mengurangi intisari dari keutuhan hakikat dan prinsip pembelajaran sehingga memiliki kemudahan, kepraktisan dan kemenarikan (Surahman, 2019).

\section{SIMPULAN}

Berdasarkan hasil uji kelayakan produk yang diujikan kepada ahli media dan ahli materi, serta dilakukan uji coba lapangan kepada siswa. Diperoleh hasil bahwa media novel chat mendapatkan tanggapan positif dan layak digunakan sebagai media pembelajaran sosiologi. Berdasarkan hasil penelitian yang sudah dilakukan, menunjukkan bahwa media novel chat dapat memberikan rasa kemudahan, kemenarikan dan motivasi siswa dalam proses pembelajaran. Bagi pengembang berikutnya disarankan mengembangkan media novel chat yang memiliki pembaharuan dibanding dengan penelitian yang sudah ada, agar lebih variatif dan lebih optimal, serta mengukur penggunaan media novel chat terhadap hasil belajar siswa.

\section{DAFTAR RUJUKAN}

Angraeny, N., \& Awaru, A. O. T. (2018). Upaya Guru Sosiologi Dalam Mengatasi Hambatan Penerapan Model-Model Pembelajaran Di Sma Negeri Kabupaten Polewali Mandar. Jurnal 
Sosialisasi: Jurnal Hasil Pemikiran, Penelitian Dan Pengembangan Keilmuan Sosiologi Pendidikan, 74-78.

Cahyani, A., Listiana, I. D., \& Larasati, S. P. D. (2020). Motivasi Belajar Siswa SMA pada Pembelajaran Daring di Masa Pandemi Covid-19. IQ (Ilmu Al-Qur'an): Jurnal Pendidikan Islam, 3(01), 123-140.

Demir, K., \& Akpinar, E. (2018). The Effect of Mobile Learning Applications on Students' Academic Achievement and Attitudes toward Mobile Learning. Malaysian Online Journal of Educational Technology, 6(2), 48-59.

Fida, A. N. (2016). Implementasi Pendidikan Multikultural Dalam Pembelajaran Sosiologi SMA. Pelita Bangsa Pelestari Pancasila, 11(2).

Gall, M. D., Gall, J. P., \& Borg, W. R. (2003). Educational Research: An Introduction. Pearson Education.

Haryati, S. (2012). Research and Development (R\&D) sebagai salah satu model penelitian dalam bidang pendidikan. Majalah Ilmiah Dinamika, 37(1), 15.

Insriani, H. (2011). Pembelajaran Sosiologi Yang Menggugah Minat Siswa. Komunitas: International Journal Of Indonesian Society And Culture, 3(1).

Kurniawan, H. (2017). Media Pembelajaran Mobile Learning Menggunakan Android (Studi Kasus: Jurusan Sistem Informasi IIB Darmajaya). Explore: Jurnal Sistem Informasi Dan Telematika (Telekomunikasi, Multimedia Dan Informatika), 8(1).

Machali, I. (2014). Kebijakan perubahan kurikulum 2013 dalam menyongsong Indonesia emas tahun 2045. Jurnal Pendidikan Islam, 3(1), 71-94.

Maksum, A. (2016). Sosiologi pendidikan. Malang: Madani.

Martha, Z. D., Adi, E. P., \& Soepriyanto, Y. (2018). E-book berbasis Mobile learning. Jurnal Kajian Teknologi Pendidikan, 1(2), 109-114.

Musahrain, M., Suryani, N., \& Suharno, S. (2017). Pengaplikasian mobile learning sebagai media dalam pembelajaran. Prosiding Seminar Nasional Teknologi Pendidikan.

Nurgiyantoro, B., \& Efendi, A. (2013). Prioritas penentuan nilai pendidikan karakter dalam pembelajaran sastra remaja. Jurnal Cakrawala Pendidikan, 3(3).

Nurhuda, T. A., Waluyo, H. J., \& Suyitno, S. (2017). Kajian sosiologi sastra dan pendidikan karakter dalam novel Simple Miracles Karya Ayu Utami serta relevansinya pada pembelajaran sastra Di SMA. Jurnal Ilmiah Didaktika: Media Ilmiah Pendidikan Dan Pengajaran, 18(1), 103-117.

Palupi, R. (2014). Hubungan Antara Motivasi Belajar Dan Persepsi Siswa Terhadap Kinerja Guru Dalam Mengelola Kegiatan Belajar Dengan Hasil Belajar IPA Siswa Kelas VIII Di SMPN N 1 Pacitan. Jurnal Teknologi Pendidikan Dan Pembelajaran, 2(2).

Primasari, D., Suyitno, S., \& Rohmadi, M. (2017). Analisis Sosiologi Sastra Dan Nilai Pendidikan Karakter Novel Pulang Karya Leila S. Chudori Serta Relevansinya Sebagai Materi Ajar Apresiasi Sastra Di Sekolah Menengah Atas. BASASTRA, 4(1), 50-64.

Rifai, A., Sulton, S., \& Sulthoni, S. (2020). Pengembangan Media Mobile Learning Sebagai Pendukung Sumber Belajar Biologi Siswa SMA. Jurnal Kajian Teknologi Pendidikan, 3(1), $10-17$.

Rumianda, L., Soepriyanto, Y., \& Abidin, Z. (2020). Gamifikasi Pembelajaran Sosiologi Materi Ragam Gejala Sosial sebagai Inovasi Pembelajaran Sosiologi Yang Aktif dan Menyenangkan. Jurnal Kajian Teknologi Pendidikan, 3(2), 125-138. 
Sari, S. D. N. (2013). Hubungan Motivasi Belajar dan Media Pembelajaran dengan Prestasi Belajar Sosiologi Siswa Kelas XI IPS SMA Negeri 3 Boyolali Tahun Ajaran 2012/2013. SOSIALITAS; Jurnal Ilmiah Pend. Sos Ant, 3(1).

Sihkabuden. (2011). Media Pembelajaran. Malang: FIP Universitas Negeri Malang.

Sudarsana, I. K. (2016). Pemikiran tokoh pendidikan dalam buku lifelong learning: Policies, practices, and programs (Perspektif Peningkatan Mutu Pendidikan di Indonesia). Jurnal Penjaminan Mutu, 2(2), 44-53.

Surahman, E. (2019). Integrated mobile learning system (imoles) sebagai upaya mewujudkan masyarakat pebelajar unggul era digital. JINOTEP (Jurnal Inovasi Dan Teknologi Pembelajaran) Kajian Dan Riset Dalam Teknologi Pembelajaran, 5(2), 50-56.

Uli, I., Sulastriana, E., \& Hajafiani, D. (2017). Pemanfaatan nilai didaktis dalam novel supernova: partikel karya dewi lestari sebagai bahan pembelajaran di sma. Edukasi: Jurnal Pendidikan, 15(1), 81-95.

Widoyoko, S. E. P., \& Rinawat, A. (2012). Pengaruh kinerja guru terhadap motivasi belajar siswa. Jurnal Cakrawala Pendidikan, 5(2).

Wijaya, E. Y., Sudjimat, D. A., Nyoto, A., \& Malang, U. N. (2016). Transformasi pendidikan abad 21 sebagai tuntutan pengembangan sumber daya manusia di era global. Prosiding Seminar Nasional Pendidikan Matematika, 1(26), 263-278. 